\title{
Marketing Strategy of Madilog Coffee Shop using Influencers through Instagram Social Media
}

\author{
Dimas Wibisono \\ Management Science Program, Faculty of Economic and Business, Universitas Alma Ata \\ E-mail: dimaswibisono@almaata.ac.id
}

\begin{abstract}
Marketing Strategy of Madilog Coffee Shop using Influencers through Instagram Social Media (Case Study at Madilog Coffee Shop). This type of research uses a qualitative research design. The number of informants in this study amounted to 4 people (1 Owner and 3 Visitors). Samples will be obtained by using a purposive sampling technique. Data collection techniques can be done by way of interviews (interviews), and observations (observations), and a combination of the three, directly from respondents selected as a sample, which includes data on the identity of respondents. Based on the results obtained using qualitative analysis, it can be concluded in this study that the reason why the marketing strategy of Madilog Coffee Shop Marketing Using Influencers Through Instagram Social Media switches from conventional ways to Instagram marketing, namely, first because of technological advances using mobile phones, consumers are more often using Instagram social media, secondly by using social media marketing especially Instagram can further reduce marketing costs, Thirdly by utilizing influencers to increase marketing on Instagram, and have a positive impact on the progress of Madilog Coffee Shop using Influencers through Instagram Social Media, finally the role of place variables / place in the marketing mix can make Madilog Coffee Shop Marketing Strategies use Influencers through Instagram Social Media to come back to Madilog Coffee Shop Marketing Strategies using This Influencer Through Social Media Instagram gives and places an attractive place for consumers and the price is also in accordance with the prices of students. The place according to the researchers is less strategic but with advances in technology and promotion strategies that Madilog Coffee Shop.
\end{abstract}

Keywords: Social Media; Instagram Marketing; Marketing Mix; Influencer

\section{INTRODUCTION}

Yogyakarta City is known as a tourist city, this is inseparable with the needs in the hotel, restaurant, and cafe sector (HORECA). Meet the lifestyle and interest in tourism that will continue to develop each year. One of the factors that enlivened the Horeka business in Yogyakarta was the coffee shop business. This can be seen the development of the number of coffee shops in Yogyakarta continues to grow rapidly. Can be seen in 2014 the number of coffee shops as many as 350 stores, continued to expand in 2015 to 600 shops until 2018 reaching around 1,100 coffee shops spread throughout the DIY region. Of course, every coffee shop implements a marketing strategy through social media by utilizing opportunities to increase sales.

The development of social media in recent years has been very fast (W. Liu et al., 2020; D. H. Ruben, 2020). Social media is a communication tool used by users in social processes 
192 | Jurnal Administrare: Jurnal Pemikiran Ilmiah dan Pendidikan Administrasi Perkantoran

Vol. 7, No. 1, january-June 2020, Pages 191-196. Pages 191-196

(Huerta-Álvarez et al., 2020; Son et al., 2019). While the word "social" is interpreted as the fact that every individual takes action that contributes to society (Y. Liu \& Bakici, 2019; Todisco et al., 2020). In research conducted by Social Wear Hootsuite in 2019 using social media in Indonesia around 150 million of the population. The survey rose $20 \%$, while mobile social media users (gadgets) were around $48 \%$ of the population.

As technology advances, open access is easier to obtain information from the desired product or service (Roldán-Álvarez et al., 2020; Sakuliampaiboon et al., 2015; Todisco et al., 2020). In the past, searching for information was very difficult and cost more time and time to market the product (Nofiana \& Sunarsi, 2020; Sunarsi, 2018a, 2018b; Yuangga \& Sunarsi, 2018). Departing with the help of technology media makes no geographical restrictions as well as marketing techniques. The advance of technology today is a new way to market, introduce, and promote an item or service in using social media. Social Media is an internet-based application that uses technology, where users can create or exchange information on the application (Brinkman et al., 2020; Cheng \& Shiu, 2020; Jiao et al., 2020; Todisco et al., 2020). In his article Virtanen et al. (2017) social media also includes collaboration, content communities, social networking sites, and virtual worlds - using the web and mobile-based technology to create highly interactive platforms where users share, share, discuss and modify user-generated content. (Kaplan \& Haenlein, 2010; Kietzmann et al., 2011). Social media that are widely used in Indonesia include Facebook, Twitter, Instagram, Pinterest, Snapchat, and others.

Instagram is an application that allows users to take photos, take videos, apply digital filters, and share them with various social networking services, including Instagram's own (Brown \& Tiggemann, 2020; Engeln et al., 2020; Parmelee \& Roman, 2020). Over time some people have realized that Instagram can be used as a medium to market a product, therefore to further enhance Instagram as a marketing medium must be supported by marketing mix theory, digital and internet marketing, this theory is very necessary and mandatory for restaurant owners to know. how to start using Instagram as a marketing medium.

Marketing through Instagram today is indeed an opportunity for business people in Indonesia. Many of them use social media like Instagram. Being able to market from goods, services, to culinary is proof that marketing through social media is the choice of business people to market and attract potential customers. By utilizing the features provided by Instagram, marketers can easily manage their accounts the way they want. Entrepreneurs in rollicking introduce their products through their Instagram accounts. Seeing a good opportunity from utilizing Instagram as a marketing communication medium, making Coffee Shop Madilog choose this way to help market its products, and to attract consumers because the process of disseminating information is very fast. Instagram can neutralize the sharing of products or services by posting or history or usual tagging friends or family.

In previous studies (Widyaningrum, 2012) in Kampung Batik Laweyan, Solo. An exploratory design study with a sample of owners and buyers in the area stated that the use of technology in terms of marketing is still very minimal and lacking, and therefore needs further counseling to utilize social media properly. Likewise with Madilog Coffee Shop which uses Instagram as a medium to introduce products and attract the attention of consumers. Only by uploading photos of the most potent copies and flavored copies, reposting photos from buyers, and short videos can attract consumers to buy the product. Furthermore, researchers want to 
learn more about Madilog Coffee Shop Marketing Strategy using Influencers through Social Media Instagram.

\section{METHOD}

This research uses qualitative research, which aims to determine the marketing strategy of Madilog coffee shop using influencers through social media Instagram. Sources of data used in this study, namely primary data and secondary data. The informants in this study were 4 people (1 owner and 3 visitors). Data collection methods, namely interviews.

\section{RESULT AND DISCUSSION}

The results of the research from the owner of Madilog Coffee Shop is that informant 1 has implemented a marketing mix well and has thought of strategies for the short and long term for the Madilog Coffee Shop in the future. Shop Madilog Coffee does not only use one approach, but informants also combine several approaches both conventional and digital, and recently informants began to develop their strategies again by utilizing a marketing mix that was collaborated with the digital world. As a result, it has a very positive impact on Coffee Shop Madilog, if the informant does not carry out this strategy, of course, Coffee shop Madilog will be defeated by the times and will end up closed. After carrying out this strategy, informants began to utilize Influencers to further increase sales and promote shop Madilog Coffee to the public. Influencers are used from out of town to inside the city.

The results of the study from the visitor side of Coffee shop Madilog namely from informant 3 gave the same results on their question of knowing this Coffee Madilog from Instagram. The reason informants want to visit Madilog Coffee Shop is because of the first place factor then promotion, products, and influencers. Finally, the informants will still visit again because the informants are comfortable with the atmosphere of the place that makes them visit again and Madilog Coffee Shop is always innovating in its food so that it keeps the informants to always visit again.

\section{Discussion}

The discussion in the research of the owner of Coffee Shop Madilog, namely Coffee Shop Madilog, has utilized the social media once for its marketing strategy. Indirectly social media marketing makes consumers interested in a brand or product in it, this is in accordance with the theory expressed by Gunelius, (2011). "Social media marketing is a form of direct or indirect marketing to build awareness, and actions for a brand, business, person, done using tools from the social web."

Currently, the owner of Coffee Shop Madilog has used Instagram as a promotional medium for Coffee Shop Madilog and is encouraged by influencers that have a more positive impact on Coffee Shop Madilog. The reason Madilog Coffee Shop uses influencers as a driver of its promotion activity is that this influencer can indirectly influence the intention to buy the product, and this step is very appropriate. The last reason is that the cost, as is known to make a promotion certainly requires no small cost. But along with the development and the existence of 
$194 \mid$ Jurnal Administrare: Jurnal Pemikiran Ilmiah dan Pendidikan Administrasi Perkantoran

Vol. 7, No. 1, january-June 2020, Pages 191-196. Pages 191-196

Instagram, to promote Madilog Coffee Shop no longer needs a large cost, and using Instagram can be more precise and go directly to consumers.

Consumer behavior theory states that to increase the likelihood and frequency of consumers making contact with products, buying and using them, and making repeat purchases, consumers can experience contact and engage with a product in a variety of different ways.

The method referred to in this study is by utilizing the role of social media in marketing, as stated by (SI, 2015) explaining there are 5 points of the role of social media in marketing, namely social media can provide an identity regarding the products offered; role as marketing research in an effort to find information about consumer needs; social media can be used as a communication link between marketing and consumers, aimed at maintaining relationships with consumers; social media brings the company closer to consumers. social media functions to show products every time; social media is intended to build customer engagement

Research by (SI, 2015) is very much in line with the results of researcher interviews, namely: all 3 informants already know the identity of Coffee Shop Madilog as a place that sells food and drinks; 3 informants coming to this Coffee Shop Madilog Store certainly the informant will shop, it is from the shopping results that the Madilog Coffee Shop knows what consumers buy and need from the most sales; This Madilog Coffee shop posts photos of new menus or products on its Instagram or with the help of influencers, of course, this aims to remind and communicate to consumers that Madilog Coffee Shop has new information about the place both in terms of products, places, prices or promotions (public and campus events and discount programs). This is in line with an interview with the owner of Coffee Shop Madilog "if our shop is obliged to promote through Instagram using influencers. The point is to attract consumers ... as if there are new products from us the same if we have a discount mas ... "; after communication between Coffee Shop Madilog and informants is well established, Coffee Shop Madilog always posts its products with a display that aims to remind consumers to visit again; the occurrence of deep customer engagement with Informants. The informant no longer buys by considering the price issue.

\section{CONCLUSION}

The conclusion of this research is why the Madilog Coffee Shop marketing strategy shifted from conventional ways to Digital Marketing with Instagram which is based on technological advances that consumers are now more inclined to use social media especially Instagram because consumers today are already saturated if Shop Madilog Coffee uses conventional methods and less positive impact for today; by using social media marketing especially Instagram can reduce costs in marketing financing; use influencers to further enhance marketing on social media Instagram, because the impact of these influencers has a more positive impact on the progress of Coffee Shop Madilog because now consumers know this Coffee Shop Madilog from influencers as well and finally the role of place variables in marketing mix can make visitors to come back to Madilog Coffee Shop provide and deliver interior and atmosphere of a place that is attractive to consumers and the price is also in accordance with the pockets of consumers (students). A place that according to researchers is less strategic but with the advancement in technology and promotion strategies that Madilog Coffee Shop is doing, it can directly touch consumers' hearts. 


\section{REFERENCES}

Brinkman, C. S., Gabriel, S., \& Paravati, E. (2020). Social achievement goals and social media. $\begin{array}{lllll}\text { Computers in Human } 111, & 106427 .\end{array}$ https://doi.org/https://doi.org/10.1016/j.chb.2020.106427

Brown, Z., \& Tiggemann, M. (2020). A picture is worth a thousand words: The effect of viewing celebrity Instagram images with disclaimer and body positive captions on women's body image. Body Image, 33, 190-198. https://doi.org/https://doi.org/10.1016/j.bodyim.2020.03.003

Cheng, C. C. J., \& Shiu, E. C. (2020). What makes social media-based supplier network involvement more effective for new product performance? The role of network structure. Journal of Business Research, 118, 299-310. https://doi.org/https://doi.org/10.1016/j.jbusres.2020.06.054

Engeln, R., Loach, R., Imundo, M. N., \& Zola, A. (2020). Compared to Facebook, Instagram use causes more appearance comparison and lower body satisfaction in college women. Body Image, 34, 38-45. https://doi.org/https://doi.org/10.1016/j.bodyim.2020.04.007

Huerta-Álvarez, R., Cambra-Fierro, J. J., \& Fuentes-Blasco, M. (2020). The interplay between social media communication, brand equity and brand engagement in tourist destinations: An analysis in an emerging economy. Journal of Destination Marketing \& Management, 16, 100413. https://doi.org/https://doi.org/10.1016/j.jdmm.2020.100413

Jiao, P., Veiga, A., \& Walther, A. (2020). Social media, news media and the stock market. Journal of Economic Behavior \& Organization, 176, 63-90. https://doi.org/https://doi.org/10.1016/j.jebo.2020.03.002

Kaplan, A. M., \& Haenlein, M. (2010). Users of the world, unite! The challenges and opportunities of Social Media. Business Horizons. https://doi.org/10.1016/j.bushor.2009.09.003

Kietzmann, J. H., Hermkens, K., McCarthy, I. P., \& Silvestre, B. S. (2011). Social media? Get serious! Understanding the functional building blocks of social media. Business Horizons. https://doi.org/10.1016/j.bushor.2011.01.005

Liu, W., Xu, W. (Wayne), \& Tsai, J.-Y. (Jenny). (2020). Developing a multi-level organizationpublic dialogic communication framework to assess social media-mediated disaster communication and engagement outcomes. Public Relations Review, 46(4), 101949. https://doi.org/https://doi.org/10.1016/j.pubrev.2020.101949

Liu, Y., \& Bakici, T. (2019). Enterprise social media usage: The motives and the moderating role of public social media experience. Computers in Human Behavior, 101, 163-172. https://doi.org/https://doi.org/10.1016/j.chb.2019.07.029

Nofiana, L., \& Sunarsi, D. (2020). The Influence of Inventory Round Ratio and Activities Round Ratio of Profitability (ROI). JASa (Jurnal Akuntansi, Audit Dan Sistem Informasi Akuntansi), 4(1), 95-103. 
196 Jurnal Administrare: Jurnal Pemikiran Ilmiah dan Pendidikan Administrasi Perkantoran

Vol. 7, No. 1, january-June 2020, Pages 191-196. Pages 191-196

Parmelee, J. H., \& Roman, N. (2020). Insta-echoes: Selective exposure and selective avoidance on Instagram. Telematics and Informatics, 52, 101432. https://doi.org/https://doi.org/10.1016/j.tele.2020.101432

Roldán-Álvarez, D., Bacelo, A., Martín, E., \& Haya, P. A. (2020). Impact of different interaction protocols on group communication, satisfaction and learning outcomes of primary school children when using multitouch tabletops. Computers \& Education, 152, 103875. https://doi.org/https://doi.org/10.1016/j.compedu.2020.103875

Ruben, D. H. (2020). Chapter 14 - Effective communication of psychological evaluation findings for the court (D. H. B. T.-B. F. Ruben (ed.); pp. 265-289). Academic Press. https://doi.org/https://doi.org/10.1016/B978-0-12-819805-6.00014-2

Sakuliampaiboon, C., Songkhla, J. N., \& Sujiva, S. (2015). Strategies of Information Communication and Technology Integration by Benchmarking for Primary School in Catholic (Layman) School Administration Club Bangkok Arch Diocese for Students' 21st Century Skill. Procedia - Social and Behavioral Sciences, 174, 1026-1030. https://doi.org/https://doi.org/10.1016/j.sbspro.2015.01.789

Son, J., Lee, H. K., Jin, S., \& Lee, J. (2019). Content features of tweets for effective communication during disasters: A media synchronicity theory perspective. International Journal of Information Management, 45, 56-68. https://doi.org/https://doi.org/10.1016/j.ijinfomgt.2018.10.012

Sunarsi, D. (2018a). Buku Ajar: Seminar Perencanaan Sumber Daya Manusia. Asmoro Mediatama.

Sunarsi, D. (2018b). Pengaruh rekrutmen, seleksi dan pelatihan terhadap produktivitas kerja karyawan. KREATIF: Jurnal Ilmiah Prodi Manajemen Universitas Pamulang, 6(1), 1431.

Todisco, L., Tomo, A., Canonico, P., Mangia, G., \& Sarnacchiaro, P. (2020). Exploring social media usage in the public sector: Public employees' perceptions of ICT's usefulness in delivering value added. Socio-Economic Planning Sciences, 100858. https://doi.org/https://doi.org/10.1016/j.seps.2020.100858

Widyaningrum, D. E. (2012). Strategi Pemasaran Kampung Batik Laweyan Solo. Jurnal Manajemen Pemasaran Universitas Indonesia.

Yuangga, K. D., \& Sunarsi, D. (2018). The Influence of Procrastination and Low Time Management on Student Self Efficacy (at MA Soebono Mantofani). PINISI Discretion Review, 2(1), 85-92. 